\title{
KUALITAS NUTRISI PAKAN LOKAL YANG DISUPLEMENTASI ZN BIOKOMPLEK DAN VITAMIN E
}

\author{
(Nutrition Quality Of Local Feed Supplemented Zn Biokomplek And Vitamin E)
}

\author{
Tintin Rostini ${ }^{1)}$, Muhammad Irwan Zakir1), Arief Hidayatulloh ${ }^{2)}$ \\ $\left.{ }^{1}\right)$ Jurusan Peternakan Fakultas Pertanian Universitas Islam Kalimantan \\ ${ }^{2}$ )Jurusan Agribisnis Fakultas Pertanian, Universitas Islam Kalimantan \\ Jln Adyaksa No 2 Kayu Tangi Banjarmasin \\ Email : tintin_rostini@yahoo.com
}

Article Submitted : 31-04-2019

Article Accepted : 10-06-2019

\begin{abstract}
The nutritional quality of local food in the poor Kalimantan region will be lacking in minerals because the place for growing forage plants in a land with margins (acid) makes the quality of mineral poor food ingredients. The purpose of this study was to determine the nutritional quality of local feed supplemented with biocomplex $\mathrm{ZN}$ and Vitamin E. The treatment in this study used a complete design (CRD) with 4 processing repetitions made from 16 experimental units, consisting of $(\mathrm{Tl})$ local forage-concentrates $12 \% \mathrm{PK}$ without $\mathrm{Zn}$ and vitamin $\mathrm{E}$ supplementation, (T 2) Tl-supplementation $+60 \mathrm{mg} \mathrm{Zn} \mathrm{/} \mathrm{kg}$ as biocomplex $\mathrm{Zn}$ and vitamin E (T3) $\mathrm{Tl}+120 \mathrm{mg} \mathrm{Zn}$ / kg such as Zn biocomplex + vitamin E and (T4) $\mathrm{Tl}+180 \mathrm{mg}$ Zn Biokomplek / kg + vitamin E. Parameters collected are the nutritional quality and digestibility of dry matter and feed organic matter. The results shown from studies using biocomplex ZN up to $180 \mathrm{mg} / \mathrm{kg}$ of feed (PT3) can increase the protein content and dry matter content of local feed, and can increase the digestibility of local dry matter and organic feed ingredients. It was concluded that $\mathrm{ZN}$ Biokomplek and Vitamin E can improve the quality of local feed.
\end{abstract}

Keywords: minerals. local food, protein, vitamins

\section{PENDAHULUAN}

Kualitas nutrisi bahan pakan lokal yang ada diwilayah Kalimantan miskin akan unsur mineral karena tempat tumbuh tanaman hijauan pada keaadaan tanah yang marjin (asam) sehingga kualitas bahan pakan miskin akan mineral (Rostini, 2014 ). Hal ini dipertegas dengan hasil penelitian Little (1986) bahwa kandungan mineral terutama $\mathrm{Zn}$ sangat marginal dari pakan tradisional, sehingga dapat menggangu kondisi fisiologis, reproduksi dan prestasi produksi ternak, terutama ternak ruminansia khususnya kambing perah,

Underwood (2001) Mengemukkan
bahwa mineral $\mathrm{Zn}$ berperan untuk

pertumbuhan dan pembelahan sel, perkembangan seksual, produksi sperma yang sehat, pembentukan embrio, berperan selama kehamilan dan mengaktifkan hormon pertumbuhan. Selain itu, Zn juga penting dalam pengecapan, serta nafsu makan. Zn merupakan komponen penting pada struktur dan fungsi membran sel. $\mathrm{Zn}$ berfungsi sebagai antioksidan, dan melindungi tubuh dari serangan lipid peroksidase $\mathrm{Zn}$ memegang peranan penting terutama dalam proses fisiologis dan metabolisme ternak. $\mathrm{Zn}$ juga berfungsi di dalam sintesis beberapa hormon seperti insulin dan glukagon, serta berperan dalam metabolisme karbohidrat, keseimbangan asam basa dan metabolisme 
vitamin A (Linder, 1992). Zn dibutuhkan oleh kerja enzim dan Zn dikenal sebagai katalisator beberapa enzim. Lebih dari 300 enzim memerlukan $\mathrm{Zn}$ seperti enzim dehidrogenase, superoksida dismutase, alkalin fosfatase, aminopeptidase, karboksipeptidase dan collagenase (Underwood, 2001).

Defisiensi mineral $\mathrm{Zn}$ akan berpengaruh pada tingkat kesuburan ternak karena mineral $\mathrm{Zn}$ turut berperan dalam proses pematangan spermatogenesis dan oogenesis. Kandungan mineral $\mathrm{Zn}$ pada pakan kasar untuk ruminansia umumnya relative rendah, sehingga banyak ditemukan kejadian defisiensi $\mathrm{Zn}$ pada ternak ruminansia. Little (1986) melaporkan kandungan $\mathrm{Zn}$ pada pakan kasar ruminansia berkisar antara $20-38 \mathrm{mg} / \mathrm{kg}$ bahan kering, sedangkan kebutuhan seng bagi ternak ruminansia sekitar 40-50 $\mathrm{mg} / \mathrm{kg}$ (Arora, 1989). Dengan demikian bisa diperkirakan bahwa ternak yang dipelihara di Indonesia berpotensi mengalami defisiensi $\mathrm{Zn}$ dan perlu diberikan suplemen. Seng (Zn) merupakan mineral mikro yang terdapat pada setiap jaringan tubuh terutama pada tulang. Tulang merupakan tempat akumulasi $\mathrm{Zn}$ yang paling tinggi bila dibandingkan dengan hati. $\mathrm{Zn}$ terdapat di dalam darah terutama di dalam eritrosit, di samping itu Zn juga ditemukan dalam konsentrasi yang cukup tinggi pada kulit, rambut dan wool. Kamal (1994) menyatakan mineral $\mathrm{Zn}$ juga terdapat pada beberapa macam enzim pencernaan. Mineral seng ( $\mathrm{Zn}$ ) sangat dibutuhkan oleh tubuh untuk memelihara fungsi tubuh dan membantu dalam proses metabolisme karbohidrat. Manfaat $\mathrm{Zn}$ di dalam tubuh ternak yaitu (1) sebagai komponen enzim tirosinase, oksidase monoamin, oksidase galaktoda oksidase sitokhrom dan anhidrase karbonat (berguna untuk pengangkutan $\mathrm{CO} 2$ di dalam sel darah merah), (2) membantu proses absorpsi Fe dari organ pencernaan, dan (3) berperan dalam proses pigmentasi yang normal pada bulu dan wool (Kamal, 1994). Seng merupakan kofaktor pada lebih dari 70 macam enzim (Broderick et al.,
1998), enzim tersebut banyak terlibat dalam proses metabolisme dan memiliki arti yang penting untuk menjaga stabilitas dan integritas biomembran. Sebagai bagian dari sistem enzim, mineral $\mathrm{Zn}$ berperan banyak dalam metabolisme karbohidrat, sintesis protein, dan metabolisme asam nukleat (NRC, 1988).

Flohe dan Traber (1999) menyatakan bahwa vitamin $\mathrm{E}$ sangat esensial untuk reproduksi. Apabila digunakansecara rutin sebagai suplemen maka vitamin $\mathrm{E}$ dapat meningkatkan pertumbuhan dan menjaga perkembangan zigot. vitamin $\mathrm{E}$ mampu mencegah kerusakan spermatozoa pada ternak jantan dan menjaga perkembangan zigot pada ternak betina. Pada proses spermatogenesis, vitamin $\mathrm{E}$ berfungsi sebagai antioksidan yang mampu menetralkan radikal bebas hasil metabolisme aerob (Ogbuewu et al., 2010). Pemberian campuran vitamin $\mathrm{E}$ dan mineral $\mathrm{Zn}$ dapat meningkatkan kualitas semen kambing Boer. Suharyati dan Hartono, (2013), Perbaikan mutu pakan juga dapat dilakukan dengan suplementasi mineral dan vitamin, seperti $\mathrm{Zn}$ dan vitamin E. Suplementasi ini dimaksudkan untuk memperbaiki metabolisme dan daya tahan tubuh. Menurut Mc Donald et al. (2002),Sedangkan Bell et al. (2006) menyatakan bahwa vitamin E bersama mineral seperti $\mathrm{Zn}$ dan Se, berperan aktif dalam metabolisme dan ketersediaan zat gizi untuk produksi susu, serta dapat meningkatkan konsentrasi beberapa komponen lemak susu

Tujuan dari penelitian ini dalah untuk mengetahui kualitas nutrisi pakan lokal yang disuplementasi ZN biokomplek dan Vitamin E.

\section{METODE PENELITIAN}

\section{Materi}

Zn biokompleks disiapkan dengan cara: pertama untuk membuat skala $5 \mathrm{~kg}$. Bahan yang digunakan adalah tepung kedelai yang telah dikukus sebagai media fermentasi . Inokulum yang digunakan adalah Sacharomyses cerevisiae. 
Fermentasi tahap pertama (semi cair): larutan Zn sulfat, larutan tepung kedelai dan inokulum dimasukkan kedalam erlenmeyer, kemudian difermentasikan pada "shaker bath" selama 48 jam pada suhu $38^{\circ} \mathrm{C}$ Fermentasi tahap ke dua (semi padat): hasil fermentasi tahap pertama selanjutnya dicampur dengan tepung kedelai kukus, lalu difermentasikan pada loyang stainless steel selama 48 jam selanjutnya digiling dan dilakukan analisis $\mathrm{Zn}$ dengan menggunakan metode Spektrometri Serapan Atom (A0AC 2000).

\section{Metode}

Perlakuan pakan lokal ini terdiri atas (Tl) hijauan lokal-konsentrat kandungan $12 \%$ PK tanpa suplementasi $\mathrm{Zn}$ dan vitamin E, (T2) T1 -suplementasi + $60 \mathrm{mg} \mathrm{Zn} \mathrm{lkg} \mathrm{sebagai} \mathrm{Zn} \mathrm{biokompleks}$ dan vitamin $\mathrm{E}$ (T3) $\mathrm{Tl}+120 \mathrm{mg} \mathrm{Zn} \mathrm{lkg}$ sebagai $\mathrm{Zn}$ biokompleks + vitamin $\mathrm{E}$ dan (T4) $\mathrm{Tl}+180 \mathrm{mg} \mathrm{Zn} \mathrm{lkg} \mathrm{sebagai} \mathrm{Zn}$ biokompleks + vitamin E.

\section{Analisis Pakan Suplementasi Zn}

\section{Biokomplek dan Vitamin $\mathbf{E}$}

Analisis nutrisi bahan kering (BK), protein kasar (PK), serat kasar (SK), dan lemak kasar (LK) dikerjakan menurut prosedur AOAC (1990). Untuk bahan ektrak tanpa $\mathrm{N}$ (Bet-N) dihitung berdasarkan: $100 \%-(\mathrm{KA}+\mathrm{abu}+\mathrm{LK}+\mathrm{PK}$ + SK). Kandungan NDF (Neutral Detergent Fiber) dan ADF (Acid Detergent Fiber) dianalisi berdasarkan metode Van Soest (1991). Mineral Ca $(\lambda 422.7 \mathrm{~nm})$ dan $\mathrm{P} \quad(\lambda=660 \mathrm{~nm})$ dianalisis menggunakan Atomic Absorbance Spectrophotometer (AAS).

\section{HASIL DAN PEMBAHASAN}

\section{Kualitas Nutrisi Pakan Lokal}

Kualitas nutrisi pakan lokal sangat dipengaruhi oleh campuran bahan-bahan pakan yang digunakan, dimana semakin banyak bahan-bahan pakan yang digunakan menunjukkan peningkatan kualitas pakan. Rataan kualitas nutrisi pakan lokal tersaji pada Tabel 1.

Tabel 1. Kandungan nutrisi pakan yang disuplementasi Zn Biokomplek dan Vitamin E

\begin{tabular}{lcccc}
\hline NUTRISI & PT0 & PT1 & PT2 & PT3 \\
\hline Bahan kering (\%) & $93.14 \pm 0,7$ & $93.07 \pm 1.2$ & $94.42 \pm 9,5$ & $94.46 \pm 0,7$ \\
Bahan organic (\%) & $84.54 \pm 0.2$ & $85.62 \pm 0,7$ & $86.81 \pm 1.1$ & $88.27 \pm 1.4$ \\
Protein kasar (\%) & $12.86 \pm 0,8$ & $13.11 \pm 0.6$ & $13.38 \pm 0.2$ & $13.67 \pm 0.7$ \\
Lemak (\%) & $3.75 \pm 0.2$ & $4.20 \pm 0.2$ & $4.43 \pm 0,6$ & $4.0 \pm 0,2$ \\
Serat kasar (\%) & $27.32 \pm 1.1$ & $27.63 \pm 0.5$ & $26.93 \pm 2.1$ & $27.74 \pm 1.6$ \\
Ca (\%) & $0.68 \pm 0,2$ & $0.60 \pm 0,2$ & $0.84 \pm 0,3$ & $0.91 \pm 0,2$ \\
P (\%) & $0.36 \pm 0,1$ & $0.43 \pm 0,2$ & $0.26 \pm 0,1$ & $0.26 \pm 0,1$ \\
\hline
\end{tabular}

Keterangan : (PT0) hijauan lokal-konsentrat kandunganl4\% PK tanpa suplementasi Zn dan vitamin E, (PT1) $\mathrm{Tl}$ - suplementasi $+60 \mathrm{mg} \mathrm{Zn} \mathrm{kg}$ sebagai $\mathrm{Zn}$ biokompleks dan vitamin $\mathrm{E}$ (PT2) $\mathrm{Tl}+120 \mathrm{mg} \mathrm{Zn} \mathrm{lkg} \mathrm{sebagai} \mathrm{Zn} \mathrm{biokompleks} \mathrm{+} \mathrm{vitamin} \mathrm{E} \mathrm{dan}$ (PT3) $\mathrm{Tl}+180 \mathrm{mg} \mathrm{Zn} \mathrm{lkg} \mathrm{sebagai} \mathrm{Zn}$ biokompleks + vitamin E.

Pakan penelitian mengandung protein kasar (PK) dengan rataan dan standar deviasi sebesar $12.86 \pm 0.23 \%$. Kandungan ini telah memenuhi kebutuhan yang disyaratkan oleh NRC (1988) sebesar $12 \%$ untuk ternak kambing. Secara kuantitatif perlakuan PT0 (pakan + tanpa campuran Zn Biokomplek dan Vitamin E) mengandung bahan organik lebih rendah dibandingkan dengan perlakuan yang ditambahkan ZN biokomplek dan Vitamin $\mathrm{E}$, diikuti dengan kandungan lemak dan 
mineral. Hasil ini sesuai dengan yang diharapkan bahwa suplementasi ini akan memperbaiki nutrisi ransum. Dimana perbaikan mutu pakan juga dapat dilakukan dengan suplementasi mineral dan vitamin, seperti $\mathrm{Zn}$ dan vitamin E. Suplementasi ini dimaksudkan untuk memperbaiki metabolisme dan daya tahan tubuh. Menurut Mc Donald et al., (2002),

Tabel 1. menunjukkan kandungan nutrisi pakan yang disuplemtasi $\mathrm{ZN}$ biokomplek dan Vitamin E, menunjukkan kandungan nutrisi yang lebih tinggi dibandingkan dengan pakan tanpa penambahan suplmentasi $\mathrm{ZN}$ Biokomplek dan Vitamin E. Hal ini menunjukkan bahwa penambahan $\mathrm{ZN}$ Biokomplek yang berasal dari tepung kedelai dapat meningkatkan kandungan Protein, dimana semakin tinggi kandungan $\mathrm{ZN}$ Biokomplek $\quad(\mathrm{PT} 3=180$ $\mathrm{mgZN}$ biokomplek/kg + vitamin E) menunjukkan kandungan protein tertinggi yaitu sebesar $13.67 \%$. hal didukung karena
$\mathrm{ZN}$ biokomplek dibuat dari tepung kedelai yang memiliki kandungan protein sebesar $37,7 \%$ sehingga dapat menigkatkan kandungan protein pakan. Hal ini Senada dengan pendapat Prasetiyono (2008), Bahwa tepung kedelai memiliki kandungan Protein yang tinggi namun mudah terdegradasi di dalam rumen. Sedangkan Rostini (2016) mengemukakan Bahwa penambahan ZN dalam Pakan dapat meningkatan metabolisme protein dalam rumen ternak.

\section{Kandungan NDF dan ADF Pakan Lokal yang disuplementasi $\mathrm{ZN}$ Biokomplek dan Vitamin E}

Kandungan NDF dan ADF pakan lokal yang disuplementasi ZN Biokomplek dan Vitamin E, menunjukkan perbedaan yang nyata $(\mathrm{P}<0.05)$ antar perlakuan. Rataan Kandungan ADF dan NDF pakan yang disuplementasi ZN Biokomplek dan Vitamin E tersaji pada Tabel 2.

Tabel 2. Kandungan ADF dan NDF pakan yang disuplementasi Zn Biokomplek dan Vitamin E

\begin{tabular}{ccccc}
\hline NUTRISIi & PT0 & PT1 & PT2 & PT3 \\
\hline NDF (\%) & $75.92 \pm 2.3$ & $75.86 \pm 1.6$ & $75.57 \pm 2,1$ & $75.34 \pm 2.2$ \\
ADF (\%) & $54.12 \pm 1.8$ & $53.87 \pm 4.1$ & $53.68 \pm 1.6$ & $43.20 \pm 3.2$ \\
\hline
\end{tabular}

Keterangan : (PT0) hijauan lokal-konsentrat kandunganl4\% PK tanpa suplementasi Zn dan vitamin E, (PГ1) $\mathrm{Tl}$ - suplementasi $+60 \mathrm{mg} \mathrm{Zn} \mathrm{lkg}$ sebagai $\mathrm{Zn}$ biokompleks dan vitamin $\mathrm{E}$ (PT2) $\mathrm{Tl}+120 \mathrm{mg} \mathrm{Zn} \mathrm{lkg} \mathrm{sebagai} \mathrm{Zn} \mathrm{biokompleks} \mathrm{+} \mathrm{vitamin} \mathrm{E} \mathrm{dan}$

(PT3) $\mathrm{Tl}+180 \mathrm{mg} \mathrm{Zn} \mathrm{lkg} \mathrm{sebagai} \mathrm{Zn} \mathrm{biokompleks} \mathrm{+} \mathrm{vitamin} \mathrm{E.}$

Hasil analisis ragam kandungan ADF dan NDF pada pakan lokal yang disuplmentasi ZN Biokomplek dan Vitamin E, tidak berpengaruh nyata $(\mathrm{P}<0.05)$ terhadap kandungan NDF dan ADF. Kandungan NDF tertinggi pada perlakuan PT0 sebesar 75.92\% sedangkan terendah pada Perlakuan PT3 sebesar 75,34\%. Hal ini menunjukkan kandungan serat pakan secara kovalen terikat sangat kuat dengan ikatan hidrogen, kristalisasi atau ikatan intramolekuler lain yang sangat resisten terhadap larutan yang masih berada pada tingkat konsentrasi physiologis, sehingga bila tidak di fermentasi tidak terjadi degrasai praksi serat.
(Anggorodi, 1979). Pada penelitian tidak terjadi penurunan kandungan NDF dan ADF, karena penambahan mineral dalam pakan secara statistik tidak dapat menurunkan kandungan fraksi serat pakan baik NDF maupun ADF walaupun ada kecenderungan penurunan. .

\section{Pengujian In-vitro Pakan lokal yang Disuplementasi ZN Biokomplek dan Vitamin E}

Suplementasi mineral dan vitamin dapat meningkatkan kecernaan bahan kerng dan bahan organik pakan (Puspitasari et al., 2015). Pengujian kecernaan secara invitro 
adalah salah satu cara untuk menguji kualitas ransum yang akan digunakan sebagai pakan ternak. Rataan kecernaan bahan kering, bhn orgnik dan NH 3 tersaji pada tabel 3.

Tabel 3. Ratan Kecernaaan Bahan Kering, Bahan organic dan NH3 secara invitro

\begin{tabular}{lcccc}
\hline \multicolumn{1}{c}{ Peubah } & PT0 & PT1 & PT2 & PT3 \\
\hline KCBK (\%) & $69.42 \pm 2.1$ & $69.17 \pm 1,4$ & $69.04 \pm 0.8$ & $68.82 \pm 1,1$ \\
KCBO $(\%)$ & $70.24 \pm 1.5$ & $73.83 \pm 1,1$ & $71.99 \pm 1.2$ & $70.33 \pm 2.2$ \\
NH3 & $9.33 \pm 0.6$ & $10.29 \pm 1.0$ & $10.79 \pm 0.7$ & $10.08 \pm 0.4$ \\
\hline
\end{tabular}

Keterangan : (PT0) hijauan lokal-konsentrat kandunganl4\% PK tanpa suplementasi Zn dan vitamin E,

(PID) $\mathrm{Tl}$ - suplementasi $+60 \mathrm{mg} \mathrm{Zn}$ lkg sebagai $\mathrm{Zn}$ biokompleks dan vitamin $\mathrm{E}$

(PT2) $\mathrm{Tl}+120 \mathrm{mg} \mathrm{Zn}$ lkg sebagai Zn biokompleks + vitamin E dan

(PT3) $\mathrm{Tl}+180 \mathrm{mg} \mathrm{Zn} \mathrm{lkg} \mathrm{sebagai} \mathrm{Zn} \mathrm{biokompleks} \mathrm{+} \mathrm{vitamin} \mathrm{E}$.

Kecernaaan Pakan lokal yang dsuplementasi ZN Bikomplek dan Vitamin E, menunjukkan perbedaan yang nyata $(\mathrm{P}<0.05)$, Namun demikian semakin tinggi nilai kecernaan maka semakin cepat pengisian melali konsumsi yang semakin tinggi. Hasil penelitian menunjukkan bahwa pakan yang disuplemntasi ZN Biokomplek dan vitamin $\mathrm{E}$ nyata meningkatkan $(\mathrm{P}<0.05)$ kecernaan bahan kering dan bahan organik. Rata-rata kecernaan berkisar 68,82- 69,42\% untuk kecernaan BK dan 70,24- 73,83\% untuk kecernaan bahan organik. Kecernaan bahan kering dan bahan organik pakan yang disuplemntasi $\mathrm{ZN}$ Biokomplek dan vitamin $\mathrm{E}$ memberikan tingkat kecernaan bahan kering dan bahan organik yang paling tinggi . Hal ini disebabkan karena serat pakan perlakuan tidak jauh berbeda antar perlakuan yaitu rataan Serat kasar sebesar $27 \%$. Hal ini senada dengan pendapat Davidson et al, (2003) menyatakan tinggnya serat kasar memberikan kontribusi pada penurunan kecernaan bahan kering dan bahan organik

Terjadi penurunan kecernaan bahan kering dan bahan organik disebabkan adanya kandungan serat kasar dari tiap-tiap perlakuan. Ada korelatif negatif antara tingkat kecernaan bahan kering dan bahan organik dengan kandungan NDF dan ADF dalam ransum Cherdthon et al, (2010). Sementara Rostini et al, (2014) menyatakan tinggnya serat kasar memberikan kontribusi paling besar terhadap pada penurunan kecernaan bahan kering dan bahan organik. Pakan. Hal ini senada dengan NRC (1988) bahwa bahwa kecernaan bahan kering dan bahan organik dipengaruhi oleh suplementasi Zn- vitamin $\mathrm{E}$, dan diduga karena peran atalitik $\mathrm{Zn}$ dan fungsi vitamin $\mathrm{E}$ dalam melindungi oksidasi lemak dan kerusakan sel. Zn dengan fungsi katalitiknya, mengaktivasi enzim yang terlibat dalam metabolisme.

Kandungan $\quad \mathrm{N}^{-\mathrm{NH}_{3}}$ merupakan indikator besarnya protein yang terdegradasi selama proses fermentasi (Kung dan Stokes, 2001). Bakteri pendegrasi protein akan merombak protein menjadi asam amino, asam amino ini selanjutnya akan dirombak menjadi produk lain seperti asam butirat, $\mathrm{N}$ NH3 dan CO2 (Moran 1996). Data hasil penelitian N-NH3 (Tabel 3) perlakuan tidak berbeda $(\mathrm{P}<0.05)$ antar perlakuan). Hal ini kemungkinan disebabkan protein pada pakan perlakuan hampir sama yaitu ratan Protein kasar sebesar $12 \%$. Konsentrasi NH3 pakan perlakuan yang disuplementasi ZN Biokomplek dan Vitamin E i masih dalam batas yang normal dalam mendukung pertumbuhan mikroba, hal ini senada dengan pendapat McDonald et al. (2002) rataan NH3 yang normal sebsar 6-21 $\mathrm{mM}$ dalam pakan. Hal ini karena protein di degradasi pada tingkat yang berbeda yang mampu memenuhi kebutuhan mikroba rumen (Sutardi 1980)

\section{KESIMPULAN}

Berdasarkan hasil dapat disimpulkan bahwa penambahan ZN Biokomplek dan Vitamin E dalam pakan lokal dapat 
meningkatkan kualitas nutrisi pakan dan dapat meningkatkan kecernaan bahan kering dan bahan organik pakal lokal.

\section{UCAPAN TERIMA KASIH}

Penelitian ini merupakan bagian dari penelitian PUPT. Kami ucapkan terimakasih disampaikan kepada Kemenristek Dikti yang telah mendanai penelitian ini dalam Skim Hibah PUPT pada tahun anggran 2018-2019.

\section{DAFTAR PUSTAKA}

Anggorodi, R. 1979. Ilmu Makanan ternak dasar Umum. Gramedia. Jakarta.

Association of Official Analytical Chemist. 1999. Official Methods of Analysis. Ed ke-16. Washington: AOAC International

Arora, SP. 1995. Pencernaan Mikroba Pada Rumininasia. Yogyakarta. Gadjah Mada university Press.

Bell JA. Griinari JM, Kennelly JJ. 2006. Effect oil, flaxseed Oil, monensin and Vitamin $\mathrm{E}$ on Concentration of Conjugated Linoleic Acid in Bovine Milk Fat, Journal dairy Science 79 (9) $: 1-8$

Broderick, G. A. and J. H. Kang. 1980. Automated simultaneous determination of ammonia and total amino acid in ruminal fluid and in vitro media. J. Dairy Sci. 63:64-75.

Davidson S, Hopkins BA, Diaz DE, Bolt SM, Brownie C, Fellner and Whitlow LW. 2003. Effect of amounts and degradability of dietry protein on lactation, nitrogen utilization and excretion in early lactation Holstein coes. J. Dairy Sci. 86:1681-1689

Flohe, R.G. and M.G. Traber. 1999. Vitamin E: Function and metabolism. J. FASEB. (13):1145-1155.
Kamal, M. 1994. Nutrisi Ternak I. Fakultas Peternakan. Gajah Mada University Press. Yogyakarta

Linder MC.1992. Biokomia Nutrisi dan Metabolisme. Jakarta. Universitas Indonesia Press.

Ogbuewu, I.P., N.O. Aladi, I.F. Etuk, M.N. Opara, M.C. Uchegbu, I.C. Ocoli, and M.U.

Iloeje. 2010. Relevance of oxygen free radicals and antioxidants in sperm production and function. Research J. Vet. Sci. (3):134-138.

NRC. National Research Council. 1981. The Water Buffalo : New Prospects for An Under Utilized Animal. Washington: National Academi Press

McDonald P, Edwards RA, Greenhalgh JFD, Morgan CA. 2002. Animal Nutrition. Ed ke-6. London: Prentice Hall.

Prasetiyono. B.W.H.E. 2008. Rekayasa suplementasi Protein pada Ransum Sapi Pedaing berbasis Jerami dan deak Padi. Program PascaSarjana. Institut Pertanian Bogor. Bogor (disertasi Doktor Peternakan)

Puspitasari, N.M, Partama I.B, G. Dan Cakra. I.G.L.O. $2015 . \quad$ Pengaruh Sumplementasi Vitamin dan Mineral Terhadap Kecernaan Nutrient dan Produk Fermentasi Rumwn Sapi Bali yang diberi Ransum Berbasis Rumput Gajah. Majalah Ilmiah Peternakan Volume 18 (3) 83-88

Rostini, T. 2014. Differences in Chemical Composotion and Nutrient Quality of Swamp Forage ensiled. International Journal of Biosciensis vo; 5(12) 145151. 
Rostini T. 2016. Suplementation ZN Organik and Lemuru oil quality Milk Etawah Crossbred Goats. International journal of Biosiencis Vol 9 (6) 366-373

SAS Institute. 1997. SAS/STAT User's Guide: Statistics. SAS Institute Inc., Cary, NC, USA.

Sutardi T, 1990. The foundation of nutrition science I. Department of Food Science Science Faculty of nimal Husbandry, University. Bogor
Van Soest PJ. 1991. Nutritional Ecology of Ruminant. Ruminant Metabolism, Butritional Strategis, The Cellulolytic Fermentation and The Chemistry of Forages and Plant Fibers. Cornel University.

Underwood, E.J. 2001. Trace Elements in Human and Animal Nutrition. 4 Ed. Academic Press. New York, San Francisco, London. 197 - 242.

Suharyati S, Hartono M. 2013. Peningkatan kualitas semen kambing Boer dengan pemberian Vitamin E dan Mineral Zn. Jurnal Kedokteran Hewan. 7(2): 91 93. 